This document is confidential and is proprietary to the American Chemical Society and its authors. Do not copy or disclose without written permission. If you have received this item in error, notify the sender and delete all copies.

\title{
New insights from zinc and copper isotopic compositions of atmospheric particulate matter from two major European cities
}

\begin{tabular}{|r|l|}
\hline Journal: & Environmental Science \& Technology \\
\hline Manuscript ID & es-2016-008639.R2 \\
\hline Manuscript Type: & Article \\
\hline Date Submitted by the Author: & $30-J u l-2016$ \\
\hline Complete List of Authors: & $\begin{array}{l}\text { Ochoa González, Raquel; Imperial College London, Earth Science and } \\
\text { Engineering } \\
\text { Strekopytov, Stanislav; Natural History Museum, Mineralogy } \\
\text { AMATO, FULVIO; CSIC, } \\
\text { Querol, Xavier; CSIC-IDAEA, Geosciences } \\
\text { Reche, Cristina; Institute for Environmental Assessment and Water } \\
\text { Research (IDFA-CSIC), } \\
\text { Weiss, Dominik; Imperial College London, Earth Science and Engineering }\end{array}$ \\
\hline
\end{tabular}




\section{New insights from zinc and copper isotopic compositions of atmospheric particulate matter from two major European cities}

${ }^{1}$ Department of Earth Science and Engineering, Imperial College London, London, SW7 2AZ, UK 
24 Keywords: $\mathrm{Zn}$ and $\mathrm{Cu}$ isotopes, source apportionment, particulate matter, traffic pollution, MC-ICP-MS, atmospheric environment

\section{Abstract}

This study reports spatial and temporal variability of $\mathrm{Zn}$ and $\mathrm{Cu}$ isotopes in atmospheric particulate matter (PM) collected in two major European cities with contrasting atmospheric pollution, Barcelona and London. We demonstrate that non-traditional stable isotopes identify source contributions of $\mathrm{Zn}$ and $\mathrm{Cu}$ and can play a major role in future air quality studies.

In Barcelona, fine PM were collected at street level at sites with variable traffic density. The isotopic signatures ranged between $-0.13 \pm 0.09$ and $-0.55 \pm 0.09 \%$ for $\delta^{66} \mathrm{Zn}_{\text {IRMM }}$ and between $+0.04 \pm 0.20$ and $+0.33 \pm 0.15 \%$ for $\delta^{65} \mathrm{Cu}_{\mathrm{AE} 633}$. Copper isotope signatures similar to $\mathrm{Cu}$ sulphides and $\mathrm{Cu} / \mathrm{Sb}$ ratios within the range typically found in brake wear suggest that non-exhaust emissions from vehicles are dominant. Negative $\mathrm{Zn}$ isotopic signatures characteristic for gaseous emissions from smelting and combustion and large enrichments of $\mathrm{Zn}$ and $\mathrm{Cd}$ suggest contribution from metallurgical industries.

In London, coarse PM collected on the top of a building over 18 months display isotope signatures ranging between $+0.03 \pm 0.04$ and $+0.49 \pm 0.02 \%$ for $\delta^{66} \mathrm{Zn}_{\text {IRMM }}$ and between $+0.37 \pm 0.17$ and $+0.97 \pm 0.21 \%$ for $\delta^{65} \mathrm{Cu}_{\mathrm{AE} 633}$. Heavy $\mathrm{Cu}$ isotope signatures (up to $+0.97 \pm 0.21 \%$ o) and higher enrichments and $\mathrm{Cu} / \mathrm{Sb}$ ratios during winter time suggest important contribution from fossil fuel combustion. The positive $\delta^{66} \mathrm{Zn}_{\text {IRMM }}$ signatures are in good agreement with signatures characteristic for ore concentrates used for the production of tires and galvanised materials, suggesting non-exhaust emissions from vehicles as the main source of Zn.

\section{Introduction}

Source identification using trace metals in atmospheric particulate matter (PM) is key to air quality programmes in major cities around the world. ${ }^{1}$ Different techniques such as principal component analysis and positive matrix factorization are typically applied, ${ }^{1,2}$ but they require in general the statistical analysis of multi-elemental datasets containing large number of samples collected over long periods. Therefore, the recently explored application of nontraditional stable isotopes for source identification of metal pollutants in the atmosphere is of great interest as it requires smaller sets of samples. ${ }^{3}$

Previous work found that the main sources of $\mathrm{Zn}$ in atmospheric PM are emissions from incineration, metal production, fossil fuel combustion and non-exhaust sources from road traffic. ${ }^{4,5} \mathrm{ZnO}$ is the dominant species emitted from tire-treads ${ }^{6}$ and has been identified in emissions from metal smelting along with $\mathrm{ZnS}^{7}$ Copper has likewise been linked to 61 multiple sources, including smelting, oil combustion, wood smoke and brake wear., ${ }^{4,9}$ 62 Copper typically occurs as oxide, silicate and carbonate, and is often associated with the organic fraction in $\mathrm{PM}^{5,10}$ 
The $\mathrm{Zn}$ isotope composition relative to the widely used standard JMC 3-0749L Lyon (expressed generally as $\delta^{66} \mathrm{Zn}_{\text {Lyon }}$ ) is mostly positive in igneous rocks, ranging between +0.2 and $+0.5 \%$ in basalts and between +0.4 and $+0.6 \%$ in more acidic rocks, e.g. in granodiorites and granites. ${ }^{11}$ The $\delta^{66} \mathrm{Zn}_{\text {Lyon }}$ of sphalerite, the major source of $\mathrm{Zn}$ concentrates used for industrial purposes, ranges typically between -0.04 and $+0.30 \%$. ${ }^{12-14}$ In contrast, combustion and smelting processes seem to produce lighter (up to $-0.52 \%$ ) and heavier $\mathrm{Zn}$ (up to $+1.49 \%$ ) in the flue gas and residues, respectively. ${ }^{13,15,16}$ These values are outside the natural range of $\mathrm{Zn}$ isotope signatures and this is likely due to evaporation and condensation processes. ${ }^{16}$ Ore tailings collected from a smelter and fly ash in different coal-fired power plants had $\delta^{66} \mathrm{Zn}_{\text {Lyon values as heavy as }+1.49 \% \text {. }}{ }^{13,16,17}$ Previous work on $\mathrm{Zn}$ isotopes in PM collected in industrial, urban and remote areas showed indeed significant isotopic variability with $\delta^{66} \mathrm{Zn}_{\text {Lyon }}$ ranging from -1.13 to $+0.33 \%$, suggesting that different sources and anthropogenic activities impart a distinctive isotopic composition to PM.$^{15,18-20}$ Zinc in PM smaller than $10 \mu \mathrm{m}\left(\mathrm{PM}_{10}\right)$ emitted from a refinery in northern France imparted light isotope signatures with $\delta^{66} \mathrm{Zn}_{\text {Lyon }}$ ranging between -0.52 and $+0.02 \%$. ${ }^{15}$ Light $\mathrm{Zn}$ was also identified in PM collected in São Paulo, with $\delta^{66} \mathrm{Zn}_{\text {Lyon }}$ ranging between -1.05 and $-0.46 \%$ in $\mathrm{PM}_{2.5-10}$ and between -1.13 and $-0.07 \%$ in $\mathrm{PM}_{2.5 .}{ }^{19}$ The isotopic composition of $\mathrm{PM}_{1}$ collected over the equatorial eastern North Atlantic region had $\delta^{66} \mathrm{Zn}_{\text {Lyon }}$ signatures ranging between $+0.03 \pm 0.04 \%$ and $+0.17 \pm 0.10 \%$. ${ }^{18}$ These values are not significantly different from the isotopic signatures of natural sphalerite but lighter than $\mathrm{PM}_{4}$ separated from soil dust collected from the Sahel region, ranging between $+0.23 \pm 0.05 \%$ and $+0.28 \pm 0.08 \%$. ${ }^{12,13,18}$ Atmospheric PM collected over the North Atlantic Ocean exhibited $\delta^{66} \mathrm{Zn}_{\text {Lyon }}$ between $+0.13 \pm 0.08$ and $+0.54 \pm 0.08 \%$ which falls within the range found for igneous rocks. ${ }^{21}$ In summary, $\mathrm{Zn}$ in natural materials including igneous rocks and minerals used in the production of ore concentrates likely has an isotope fingerprint between +0.2 and $+0.6 \%$, while residues and particles produced by smelting, refining and combustion processes have isotope signatures outside this range.

Copper isotopes were investigated for their potential to identify source contributions in surface and groundwater, and in soils near mines or smelters. ${ }^{22-26}$ The average $\mathrm{Cu}$ isotope composition expressed as $\delta^{66} \mathrm{Cu}_{\text {NIST976 }}$ for chalcopyrite $\left(\mathrm{CuFeS}_{2}\right)$ is $+0.32 \pm 0.04 \%$. ${ }^{27}$ The $\delta^{65} \mathrm{Cu}_{\mathrm{NIST} 976}$ values in other natural minerals vary between -16.96 and $+9.98 \%$, but most signatures fall within the range of -1.5 and $+2.5 \%{ }^{22,27-30}$ Copper isotope signatures are variable within and between mineral groups, including native $\mathrm{Cu}$ or $\mathrm{Cu}$ sulphides and carbonates. $^{27}$ Studies assessing the potential of $\mathrm{Cu}$ isotopes for tracing source contributions

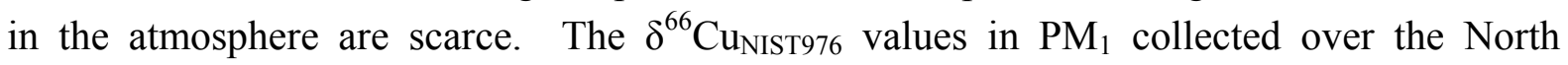
Atlantic Ocean (West Africa) ranged between $-0.14 \pm 0.09$ and $-0.02 \pm 0.10 \%$. ${ }^{18}$ These signatures were slightly more negative than the isotopic signatures in Sahel soil dust, which ranged between $+0.03 \pm 0.12$ and $+0.20 \pm 0.16 \%$. ${ }^{18}$ The $\mathrm{Cu}$ isotope signatures in PM collected over the North Atlantic Ocean ranged between $-0.18 \pm 0.11$ and $+0.30 \pm 0.11 \%$. ${ }^{21}$ Changes in mineralogy and mixing with industrial emissions from North Africa were suggested as possible mechanisms for the variability of $\mathrm{Cu}$ isotope signatures. ${ }^{18,21}$ 
Emissions from fossil fuel combustion are likely more important during winter in Europe and soil dust and non-exhaust vehicle emission sources (tires, brakes or brake discs) are likely to dominate during spring and summer. ${ }^{31}$ Therefore, significant temporal variability in source contributions of trace metals is expected in urban PM. This should be reflected in the $\mathrm{Zn}$ and $\mathrm{Cu}$ isotope signatures in PM collected during different seasons. This hypothesis, however, has not been tested before and, indeed, there is a lack of knowledge on both the spatial and temporal variability of $\mathrm{Zn}$ and $\mathrm{Cu}$ isotopes in atmospheric PM.

The aim of this study was to assess spatial, and short and long temporal variations of $\mathrm{Zn}$ and $\mathrm{Cu}$ isotope signatures in PM collected in Barcelona and London and to test associations with pollution sources. London and Barcelona have been selected in this study due to their contrasting sources of metals in PM following the findings of previous studies. ${ }^{32-34}$ In London, studies based on particle size distributions and traffic tracers $(\mathrm{Cu}, \mathrm{Fe}, \mathrm{Sb}$ and $\mathrm{Ba})$ indicate that the sources of PM are dominated by non-exhaust traffic emissions from vehicles; in Barcelona, metallurgical emissions, characterised mainly by high $\mathrm{Pb}$ and $\mathrm{Zn}$ concentrations, contribute significantly to the metal burden of the city. ${ }^{32-34}$ To this end, we first determined the spatial and short-term temporal variability of $\mathrm{Zn}$ and $\mathrm{Cu}$ isotope signatures in $\mathrm{PM}_{10}$ collected at sites with low and high traffic density at street level over two sampling campaigns during autumn of 2012 and spring of 2013 in Barcelona. Long-term seasonal variability, and hence possible influence of fuel burning, at elevated heights was evaluated using continuous sampling of $\mathrm{PM}_{2.5-80}$ during 18 months in London. Enrichment factors (EF) of elemental tracers for non-exhaust traffic emissions (Fe for brake discs and $\mathrm{Sb}$ for brakes) and for metallurgical emissions $(\mathrm{Cd}),{ }^{7}$ were determined to assist possible source attribution. Finally, the results were compared with previously reported $\mathrm{Zn}$ and $\mathrm{Cu}$ isotope signatures in atmospheric and anthropogenic PM to critically assess if it is possible to pinpoint anthropogenic sources.

\section{Materials and Methods}

\section{Sample collection and digestion}

133 In Barcelona, $\mathrm{PM}_{10}$ were sampled at street level at sites located in areas with high and low traffic using high volume samplers (MCV PM1025 and DIGITEL DH80) for 24 or $48 \mathrm{~h}$ on quartz fiber filters (Ø15 cm, Pallflex or Munktell). Filters were collected at a height of $3 \mathrm{~m}$ over a period of three weeks during two sampling campaigns in 2012 and 2013. Twelve samples were collected at Torre Girona (B1-B6) and Corsega Avenue (T1-T6) during February and March 2012, and eight samples at Palau Reial (B7-B10) and Valencia Avenue (T7-T10) during June 2013. Valencia Avenue and Corsega Avenue are the high traffic sites (14,000 and 11,000 veh day ${ }^{-1}$, respectively). Torre Girona and Palau Reial represent sites with low traffic and are situated $20 \mathrm{~km}$ away from a metallurgical industry. A map showing the monitoring locations and further information about the studied area is given in the

143 Supporting Information (Figure S1). Half of each filter was digested using $2.5 \mathrm{ml}$ of $16 \mathrm{M}$ $144 \mathrm{HNO}_{3}$ and $5 \mathrm{ml}$ of $28 \mathrm{M} \mathrm{HF}$ in PFA vials (Savillex, MN, USA) at $140{ }^{\circ} \mathrm{C}$ on a hotplate for 24 $145 \mathrm{~h}$. Then, $2 \mathrm{ml}$ of $\mathrm{HClO}_{4}(65-71 \% \mathrm{w} / \mathrm{w})$ were added to oxidise the organic matter and the residual samples were digested until complete dissolution. $10 \mathrm{mg}$ of Standard Reference 
147 Material (SRM) NIST-1648a (urban particulate matter) and $50 \mathrm{mg}$ of certified reference 148 material (CRM) BHVO-2 (basalt) from USGS were processed following the same protocol. 149 The solutions were dried down at $230{ }^{\circ} \mathrm{C}$ and then re-fluxed and evaporated twice in $0.3 \mathrm{ml}$ 150 of ca. $16 \mathrm{M} \mathrm{HNO}_{3}$ to remove the excess of fluorides. The digested solutions were re-fluxed 151 in $300 \mu \mathrm{l}$ of $7 \mathrm{M} \mathrm{HCl}$ and then re-dissolved in $4 \mathrm{ml}$ of $7 \mathrm{M} \mathrm{HCl}$ for analysis. $\mathrm{HNO}_{3}, \mathrm{HF}$ and $152 \mathrm{HCl}$ purified by sub-boiling distillation in quartz stills and high purity $\mathrm{HClO}_{4}(\mathrm{SpA}$ grade, 153 Romil Ltd) were used.

154 To assess the long-term variability of $\mathrm{Zn}$ and $\mathrm{Cu}$ isotope signatures in coarse $\mathrm{PM}$ at building height, the passive sampler Sigma-2 (Deutscher Wetterdienst) was set up approx. 20 $\mathrm{m}$ above the street level on the top roof of the Royal School of Mines, Imperial College London. This location is close to roads with high traffic densities (Cromwell Road, Exhibition Road, and Kensington Road). Twelve samples were taken at intervals of approx. five weeks over a period of 18 months between February 2014 and August 2015. The Sigma2 passive sampler is widely used to monitor continuously atmospheric particles with a size range from 2.5 to $80 \mu \mathrm{m}\left(\mathrm{PM}_{2.5-80}\right)$ that are deposited via sedimentation into a small receptor dish that has a diameter of $5.5 \mathrm{~cm}^{35}$ The dish was acid-cleaned with $4 \mathrm{M} \mathrm{HNO}_{3}, 3 \mathrm{M} \mathrm{HCl}$ and $2 \mathrm{M}$ distilled $\mathrm{HNO}_{3}$. The concentrations are given as mass of the elements deposited in the receptor dish per day $\left(n g d^{-1}{ }^{-1}\right)$. The samples were transferred from the receptor dish into PFA vials (Savillex, USA) with $15 \mathrm{ml}$ of $0.1 \mathrm{M} \mathrm{HNO}_{3}$ and then dried down for subsequent acid digestion. The samples and aliquots of NIST-1648a and BHVO-2 were digested by refluxing in closed vials using a mixture of $3 \mathrm{ml}$ of $\mathrm{HNO}_{3}, 1 \mathrm{ml}$ of $\mathrm{HF}$ and $0.5 \mathrm{ml}$ of $\mathrm{HClO}_{4}$ over four days on a hot plate at $140{ }^{\circ} \mathrm{C}$. Solutions were evaporated to dryness at $230{ }^{\circ} \mathrm{C}$, refluxed in ca. $16 \mathrm{M} \mathrm{HNO}_{3}$ and $7 \mathrm{M} \mathrm{HCl}$, evaporated again and re-dissolved in $2 \mathrm{ml}$ of $7 \mathrm{M}$ $\mathrm{HCl}$ for subsequent analysis.

Two samples of $\mathrm{Zn}$ ore concentrates from mines in Kazakhstan were purchased from Alex Stewart International to constrain the isotope signature of $\mathrm{Zn}$ used for the manufacturing of non-combustion vehicle sources like tires and galvanized steel parts. The samples were ground in an agate pestle and mortar, and digested along with BHVO-2 in duplicate in Teflon vessels in a microwave (Milestone Ethos). Aliquots of $30 \mathrm{mg}$ were digested using a mixture of $6 \mathrm{ml}$ and $2 \mathrm{ml}$ of $\mathrm{HNO}_{3}$ and $\mathrm{HF}$, respectively, and dried down and re-dissolved in $7 \mathrm{M} \mathrm{HCl}$ for subsequent analysis.

\section{Determination of element concentrations, enrichment factors and isotope ratios}

Samples were prepared in Class 10 laminar flow hoods hosted in metal-free Class 1000 clean laboratories. Dilute acid solutions were prepared using $18.2 \mathrm{M} \Omega$ grade water (Millipore system, USA).

An aliquot of the digested PM was used for elemental analysis by quadrupole inductively couple plasma mass spectrometry (Q-ICP-MS) using an Agilent 7700x, while the concentrations in the ore concentrates were determined by inductively coupled plasma optical emission spectroscopy (ICP-OES) using a Thermo iCap 6500 Duo. The accuracy of the methods was evaluated by using NIST-1648a and BHVO-2 for all elements used in this study $(\mathrm{Cu}, \mathrm{Zn}, \mathrm{Fe}, \mathrm{Al}, \mathrm{Sb}, \mathrm{Cd})$ and was within the precision of the certified values. 
The anthropogenic contribution of $\mathrm{Zn}, \mathrm{Cu}, \mathrm{Fe}, \mathrm{Sb}$ and $\mathrm{Cd}$ in the $\mathrm{PM}$ was assessed calculating EF using $\mathrm{Al}$ as reference element and the upper continental crust as reference reservoir: ${ }^{36}$

$$
\mathrm{EF}=\frac{\mathrm{C}_{\mathrm{x}, \mathrm{s}} / \mathrm{C}_{\mathrm{Al}, \mathrm{s}}}{\mathrm{C}_{\mathrm{x}, \mathrm{c}} / \mathrm{C}_{\mathrm{Al}, \mathrm{c}}}
$$

where $\mathrm{C}_{\mathrm{x}, \mathrm{s}}$ and $\mathrm{C}_{\mathrm{Al}, \mathrm{s}}$ represent the concentrations of the element $\mathrm{x}$ and $\mathrm{Al}$ in the sample, respectively, and $\mathrm{C}_{\mathrm{x}, \mathrm{c}}$ and $\mathrm{C}_{\mathrm{Al}, \mathrm{c}}$ represent their concentrations in the upper continental crust. Enrichment factors higher than 5.0 are considered as significant. ${ }^{37}$

Separation of $\mathrm{Zn}$ and $\mathrm{Cu}$ from the sample matrix prior to isotope analysis was achieved using anion-exchange chromatography. ${ }^{18,38}$ To this end, $0.7 \mathrm{ml}$ of Bio-Rad AG MP-1 resin (100-200 mesh) was added to Bio-Rad polypropylene columns with $2 \mathrm{ml}$ of resin reservoir. The $\mathrm{Zn}$ fraction was collected in PFA vials, dried down on a hot plate at $120^{\circ} \mathrm{C}$ and treated with $0.3 \mathrm{ml}$ of ca. $16 \mathrm{M} \mathrm{HNO}_{3}$ to digest any organic column residue. The solution was dried again and re-dissolved in $2 \mathrm{ml}$ of $0.1 \mathrm{M} \mathrm{HNO}_{3}$ for isotopic analysis. The $\mathrm{Cu}$ fraction was dried down, refluxed, re-dissolved in $0.3 \mathrm{ml}$ of $7 \mathrm{M} \mathrm{HCl}$, and further purified using an inhouse made Teflon column of $200 \mu \mathrm{l}$ of resin reservoir containing $150 \mu \mathrm{l}$ of the same resin. Possible effect of isotope fractionation during the ion exchange procedure was addressed by achieving complete recovery of $\mathrm{Cu}(96-108 \%)$.

Isotope ratios of $\mathrm{Zn}$ and $\mathrm{Cu}$ were determined using a $\mathrm{Nu}$ Plasma multi collector ICPMS (Nu Instruments Limited, UK) equipped with a Nu DSN-100 Desolvation Nebulizer System and a glass nebulizer $\left(100 \mu \mathrm{min}^{-1}\right)$. The isotopes ${ }^{62} \mathrm{Ni},{ }^{63} \mathrm{Cu},{ }^{64} \mathrm{Zn},{ }^{65} \mathrm{Cu},{ }^{66} \mathrm{Zn},{ }^{67} \mathrm{Zn}$ and ${ }^{68} \mathrm{Zn}$ were measured simultaneously and the calculated isotope ratios are referenced to IRMM-3702 and ERM-AE633 for $\mathrm{Zn}$ and $\mathrm{Cu}$, respectively. Isobaric interferences of ${ }^{64} \mathrm{Ni}$ were monitored measuring the intensity of ${ }^{62} \mathrm{Ni}$ but were negligible for all the analysis performed in this study. All samples were scanned for elements such as $\mathrm{Na}, \mathrm{Mg}, \mathrm{Ca}, \mathrm{Ba}$, etc, that would cause polyatomic interferences on the plasma. ${ }^{39}$ The concentrations of the interfering elements in the fractions were below the detection limit, except for $\mathrm{Ca}$ and $\mathrm{Fe}$ that were below $0.36 \%$ and $0.25 \%$ of the total amount in the sample loaded onto the columns, respectively, and were not affecting the accuracy of the isotope ratio analysis. Instrumental mass bias effects were corrected using an in-house ${ }^{64} \mathrm{Zn}-{ }^{67} \mathrm{Zn}$ double-spike for $\mathrm{Zn}$ and standard sample bracketing for $\mathrm{Cu}^{40,41}$ Further analytical details of the anion-exchange procedure, spike calibration and mass bias corrections are given in the Supporting Information. The $\mathrm{Zn}$ and $\mathrm{Cu}$ isotope ratios are reported as $\delta^{66} \mathrm{Zn}_{\text {IRMM }}$ and $\delta^{66} \mathrm{Cu}_{\mathrm{AE} 633}$ according to Eq. 2 and Eq. 3:

$$
\begin{aligned}
& \delta^{66} \mathrm{Zn}_{\text {IRMM }}=\left[\frac{\left({ }^{66} \mathrm{Zn} /{ }^{64} \mathrm{Zn}\right)_{\text {sample }}}{\left({ }^{66} \mathrm{Zn} /{ }^{64} \mathrm{Zn}\right)_{\text {IRMM }}}-1\right] \times 1000 \\
& \delta^{65} \mathrm{Cu}_{\mathrm{AE} 633}=\left[\frac{\left({ }^{65} \mathrm{Cu} /{ }^{63} \mathrm{Cu}\right)_{\text {sample }}}{\left({ }^{65} \mathrm{Cu} /{ }^{63} \mathrm{Cu}\right)_{\text {AE } 633}}-1\right] \times 1000
\end{aligned}
$$

Previously published $\mathrm{Zn}$ and $\mathrm{Cu}$ isotope ratios referring to JMC 3-0749L Lyon and NIST 976 standards were recalculated to IRMM-3702 and SRM AE633 using an isotopic offset of $+0.32 \%$ for $\mathrm{Zn}$ and no isotopic offset for $\mathrm{Cu}^{11,42}$ The analytical precision of the isotope 
227

228

229

230

231

232

233

234

235

236

237

238

239

240

241

242

243

244

245

246

247

248

249

250

251

252

253

254

255

256

257

258

259

260

261

262

263

264

265

266

267

analysis of individual samples (2SD) has been assessed using one passage of the digested sample and at least three individual sample measurements. Accuracy and reproducibility were assessed for each analytical session by repeated measurements of BHVO-2 and commercial single element solutions (denoted as Romil $\mathrm{Zn}$ and Romil $\mathrm{Cu}$ ). The isotopic composition for BHVO-2 $\left(\delta^{66} \mathrm{Zn}_{\text {IRMM }}=+0.11 \pm 0.25 \%\right.$, $\left.\mathrm{n}=5\right)$, Romil $\mathrm{Zn}(-9.10 \pm 0.10 \%$, $\mathrm{n}=4)$ and Romil $\mathrm{Cu}\left(\delta^{65} \mathrm{Cu}_{\mathrm{AE} 633}=+0.18 \pm 0.05 \%\right.$ o, $\left.\mathrm{n}=4\right)$ are in good agreement with previous published data. $^{42}$ Average isotopic compositions of NIST-1648a determined from individual analytical sessions over six months were $\delta^{66} \mathrm{Zn}_{\text {IRMM }}=-0.19 \pm 0.15 \%$ o $(\mathrm{n}=6)$ and $\delta^{65} \mathrm{Cu}_{\mathrm{AE} 633}=$ $+0.11 \pm 0.20 \%$ o $(\mathrm{n}=6)$.

\section{Results and Discussion}

\subsection{Spatial and temporal variability of concentrations, enrichment factors and isotope ratios in $\mathbf{P M}_{10}$ in Barcelona}

Table 1 shows concentrations ( $\mathrm{Zn}, \mathrm{Cu}, \mathrm{Fe}, \mathrm{Sb}$ and $\mathrm{Cd}), \mathrm{EF}\left(\mathrm{EF}_{\mathrm{Zn}}, \mathrm{EF}_{\mathrm{Cu}}, \mathrm{EF}_{\mathrm{Fe}}, \mathrm{EF}_{\mathrm{Sb}}\right.$ and $\left.\mathrm{EF}_{\mathrm{Cd}}\right)$, and isotope signatures $\left(\delta^{66} \mathrm{Zn}_{\text {IRMM }}\right.$ and $\left.\delta^{65} \mathrm{Cu}_{\mathrm{AE} 633}\right)$ determined in $\mathrm{PM}_{10}$ collected in Barcelona at sites with low (Torre Girona and Palau Reial) and high (Corsega Avenue and Valencia Avenue) traffic occurrence during 2012 and 2013.

The concentrations of $\mathrm{Cu}, \mathrm{Fe}$ and $\mathrm{Sb}$ are higher at the sites with high traffic (T1-T10) than at the sites with low traffic (B1-B10). During February and March 2012, the concentrations of $\mathrm{Cu}\left(76 \pm 31 \mathrm{ng} \mathrm{m}^{-3}\right), \mathrm{Fe}\left(1543 \pm 631 \mathrm{ng} \mathrm{m}^{-3}\right)$ and $\mathrm{Sb}\left(8 \pm 4 \mathrm{ng} \mathrm{m}^{-3}\right)$ in the $\mathrm{PM}_{10}$ collected at Corsega Avenue are significantly higher than those measured at the low traffic site in Torre Girona (Table 1). The concentrations of $\mathrm{Zn}$ and $\mathrm{Cd}$, in contrast, are similar at both sites. The sampling campaign during June 2013 shows higher concentrations of $\mathrm{Cu}$ $\left(53 \pm 15 \mathrm{ng} \mathrm{m}^{-3}\right), \mathrm{Fe}\left(1140 \pm 317 \mathrm{ng} \mathrm{m}^{-3}\right)$ and $\mathrm{Sb}\left(6 \pm 3 \mathrm{ng} \mathrm{m}^{-3}\right)$ at Valencia Avenue compared to Palau Reial (low traffic site). The concentrations of all the elements are higher in autumn 2012 than in spring 2013, possibly reflecting drier weather conditions leading to decreased deposition. $^{43}$

We find large enrichments of $\mathrm{Cu}, \mathrm{Fe}$ and $\mathrm{Sb}$, which reflect significant anthropogenic contribution (Figure S4). The $\mathrm{EF}$ are higher at Valencia Avenue $\left(\mathrm{EF}_{\mathrm{Fe}}=5.7 \pm 0.6, \mathrm{EF}_{\mathrm{Cu}}=\right.$ $268 \pm 26$ and $\left.\mathrm{EF}_{\mathrm{Sb}}=8678 \pm 596\right)$ and Corsega Avenue $\left(\mathrm{EF}_{\mathrm{Fe}}=3.1 \pm 0.9, \mathrm{EF}_{\mathrm{Cu}}=155 \pm 47\right.$ and $\mathrm{EF}_{\mathrm{Sb}}=4282 \pm 1239$ ) than at Palau Reial and Torre Girona (Table 1), respectively. The $\mathrm{EF}_{\mathrm{Zn}}$ and $\mathrm{EF}_{\mathrm{Cd}}$, in contrast, are similar at the low and high traffic sites. The $\mathrm{EF}_{\mathrm{Zn}}$ ranges between 77 and 180 and between 172 and 347 during 2012 and 2013, respectively. The $\mathrm{EF}_{\mathrm{Cd}}$ ranges between 67 and 381, except in sample T6, and between 132 and 312 during 2012 and 2013, respectively (Table 1). The $\mathrm{EF}_{\mathrm{Zn}}, \mathrm{EF}_{\mathrm{Cu}}$ and $\mathrm{EF}_{\mathrm{Sb}}$ in Valencia Avenue are significantly higher than those in Corsega Avenue which averages 3000 vehicles day $^{-1}$ less.

The isotope ratios of $\mathrm{Zn}$ and $\mathrm{Cu}$ are shown in Figure 1. Zinc is isotopically light with $\delta^{66} \mathrm{Zn}_{\text {IRMM }}$ ranging between $-0.13 \pm 0.09$ and $-0.51 \pm 0.05 \%$ (Table 1 ). The temporal (between sampling campaigns) and spatial (between sites) variability are significant relative to the 
268 typical average internal precision of $0.07 \%$ for each isotope ratio measurement. Isotopic 269 light $\mathrm{Zn}$ found in $\mathrm{PM}_{10}$ and emissions from high temperature industrial activities ${ }^{15,16}$ are in 270 line with our results suggesting important contribution from metallurgical processes in PM in 271 Barcelona. ${ }^{32,33}$ The insignificant correlations between $\delta^{66} \mathrm{Zn}_{\mathrm{IRMM}}$ and $\mathrm{EF}_{\mathrm{Zn}}$ and $\mathrm{EF}_{\mathrm{Sb}}$ (Figure 272 2a and $2 b$ ), and the weak correlation between $\mathrm{EF}_{\mathrm{Zn}}$ and $\mathrm{Sb}$ and $\mathrm{Fe}$ which are well established 273 tracers for brake wear particles (Figure 3a) support this hypothesis. Furthermore, samples 274 with negative isotope signatures at Torre Girona and Palau Reial, i.e., the sites located close to the metallurgical industry in Barcelona, are also enriched in $\mathrm{Zn}$ and $\mathrm{Cd}$ (Figure S4).

The spatial and temporal variations of $\delta^{65} \mathrm{Cu}_{\mathrm{AE} 633}$ range between $+0.04 \pm 0.20$ and $+0.33 \pm 0.15 \%$ o (Table 1 ), with one negative value measured in sample B3 $\left(\delta^{65} \mathrm{Cu}_{\mathrm{AE} 633}=\right.$ $-0.43 \pm 0.10 \%$ ). Significant correlations between $\delta^{65} \mathrm{Cu}_{\mathrm{AE} 633}$ and $\mathrm{EF}_{\mathrm{Cu}}$ and $\mathrm{EF}_{\mathrm{Sb}}$ (Figures $2 \mathrm{~d}$ and $2 \mathrm{e}$ ) suggest that the observed $\mathrm{Cu}$ isotope signature is controlled by non-exhaust vehicle emissions, i.e., brake wear. ${ }^{44}$ This is indeed supported by the strong positive correlation between the $\mathrm{EF}_{\mathrm{Cu}}$ and $\mathrm{EF}_{\mathrm{Fe}}\left(\mathrm{R}^{2}=0.9722\right)$ and the $\mathrm{EF}_{\mathrm{Cu}}$ and $\mathrm{EF}_{\mathrm{Sb}}\left(\mathrm{R}^{2}=0.9305\right)$ (Figure 3b). Consequently, an estimated $\mathrm{Cu}$ isotope signature for brake-derived particles of $\delta^{65} \mathrm{Cu}_{\mathrm{AE} 633}=$ $+0.18 \pm 0.14 \%$ o ( $n=19$, except B3) can be proposed using the average isotopic composition of the $\mathrm{PM}_{10}$. This in line with the $\delta^{65} \mathrm{Cu}_{\mathrm{AE} 633}$ determined for primary $\mathrm{Cu}$ sulphides ranging between -1 and $+1 \%$, ${ }^{22}$ and $\mathrm{Cu}$ sulphides being the dominant chemical species in brake lining materials. ${ }^{44,45}$ Sample B3 has a very light $\mathrm{Cu}$ isotope signature along with a low $\mathrm{EF}_{\mathrm{Cu}}$ $\left(\mathrm{EF}_{\mathrm{Cu}}=43\right)$ and $\mathrm{EF}_{\mathrm{Sb}}\left(\mathrm{EF}_{\mathrm{Sb}}=1327\right)$ (Figures $2 \mathrm{~d}$ and $\left.2 \mathrm{e}\right)$. This light signature may be explained by the temporal contribution from flue gas emissions from the metallurgical industry, which in fact has been previously proposed to explain the enrichment of $\mathrm{Cu}$ in PM in Barcelona. ${ }^{32,33}$

\subsection{Spatial and temporal variability of concentrations, enrichment factors and isotope ratios in $\mathbf{P M}_{2.5-80}$ in London}

Table 1 shows concentrations ( $\mathrm{Zn}, \mathrm{Cu}, \mathrm{Fe}, \mathrm{Sb}$ and $\mathrm{Cd}), \mathrm{EF}\left(\mathrm{EF}_{\mathrm{Zn}}, \mathrm{EF}_{\mathrm{Cu}}, \mathrm{EF}_{\mathrm{Fe}}, \mathrm{EF}_{\mathrm{Sb}}\right.$ and $\left.\mathrm{EF}_{\mathrm{Cd}}\right)$, and isotope signatures $\left(\delta^{66} \mathrm{Zn}_{\text {IRMM }}\right.$ and $\left.\delta^{65} \mathrm{Cu}_{\mathrm{AE} 633}\right)$ determined in PM collected using a passive sampler in London.

Elemental concentrations and EF were low during February 2014 (sample S1) and between November 2014 and February 2015 (samples S7, S8 and S9). This is likely because of high wet depositional flux of particles during periods of rain associated with the winter season in London. ${ }^{46}$

The $\delta^{66} \mathrm{Zn}_{\text {IRMM }}$ values vary between $+0.03 \pm 0.04$ and $+0.49 \pm 0.02 \%$ (Table 1 ) and correlate positively with the $\mathrm{EF}_{\mathrm{Zn}}$, except sample $\mathrm{S} 5$ which was collected between September and October 2014 (Figure 2a). The different $\delta^{66} \mathrm{Zn}_{\mathrm{IRMM}}$ and significantly high $\mathrm{EF}_{\mathrm{Zn}}$ and $\mathrm{EF}_{\mathrm{Cd}}$ for sample S5 (Table 1) indicate additional sources. The $\delta^{66} \mathrm{Zn}_{\text {IRMM }}$ values are weakly correlated with $\mathrm{EF}_{\mathrm{Sb}}$ (Figure 2c), suggesting some contribution from brake wear. The samples

307 S6, S7, S9 and S12 have the highest $\mathrm{EF}_{\mathrm{Zn}}$ and $\delta^{66} \mathrm{Zn}_{\text {IRMM }}$ values close to $0.00 \%$. The $308 \delta^{66} \mathrm{Zn}_{\text {IRMM }}$ in the PM enriched in $\mathrm{Zn}$ agree well with those found for $\mathrm{ZnO}$ which is added to 
309 tire-tread rubber to facilitate the vulcanization process, ${ }^{14}$ and with ore concentrates (mainly 310 sphalerite) analysed in our study $\left(\delta^{66} \mathrm{Zn}_{\text {IRMM }}=+0.03 \pm 0.10 \%\right.$, two samples $)$. Particles from 311 tire wear are in general larger than $10 \mu \mathrm{m},{ }^{44,45}$ and therefore have possibly been preferentially

312

313

314

315

316

317

318

319

320

321

322

323

324

325

326

327

328

329

330

331

332

333

334

335

336

337

338

339

340

341

342

343

344

345

346

347

348

349 accumulated in the passive sampler, supporting further contribution from tire wear.

The $\delta^{65} \mathrm{Cu}_{\mathrm{AE} 633}$ values vary between $+0.37 \pm 0.17$ to $+0.97 \pm 0.21 \%$ (Table 1 ). These values are significantly heavier than in $\mathrm{PM}_{10}$ collected in Barcelona. We find significant isotope variability over the entire time period assessed, but most notable are the heavier $\delta^{65} \mathrm{Cu}_{\mathrm{AE} 633}$ signatures found in samples $\mathrm{S} 6, \mathrm{~S} 7, \mathrm{~S} 8$ and $\mathrm{S} 9$ collected during winter and end of autumn (Figure 1b). This could suggest that emissions from fossil fuel combustion control significantly the isotope signatures, with a maximum peak on $\delta^{65} \mathrm{Cu}_{\mathrm{AE} 633}$ during November and December 2014 (S7). The $\mathrm{Cu} / \mathrm{Sb}$ ratio of brake wear is typically $4.6 \pm 2.3$. $^{47,54} \mathrm{The} \mathrm{Cu} / \mathrm{Sb}$ ratios in PM collected during winter in London (Table 1) are well above this value which supports an important contribution from fuel or oil combustion.

\subsection{Conceptual models for the controls of $\mathrm{Zn}$ and $\mathrm{Cu}$ isotope fingerprints in particulate matter in Barcelona and London}

Figure 4 shows preliminary conceptual models summarizing the possible controls of $\mathrm{Zn}$ and $\mathrm{Cu}$ isotope signatures in fine and large PM collected in Barcelona and London, respectively. These models warrant further work; however, they form an important starting point for the possible inclusion of these isotope systems in air quality studies.

In Barcelona, we propose that the isotope signatures identify significant contributions from emissions from metallurgical and non-exhaust vehicle emissions for $\mathrm{Zn}$ and $\mathrm{Cu}$ in $\mathrm{PM}_{10}$, respectively. The influence of emissions from metallurgy for $\mathrm{Zn}$ is supported by (i) the lack of correlation between $\delta^{66} \mathrm{Zn}_{\text {IRMM }}$ and the $\mathrm{EF}_{\mathrm{Sb}}$ (Figure $2 \mathrm{~b}$ ), and between the $\mathrm{EF}_{\mathrm{Zn}}, \mathrm{EF}_{\mathrm{Sb}}$ and $\mathrm{EF}_{\mathrm{Fe}}$ (Figure 3); (ii) the high variability in the $\delta^{66} \mathrm{Zn}_{\text {IRMM }}$ at the low and high traffic sites, and the similarity in the $\mathrm{EF}_{\mathrm{Cd}}$ and $\mathrm{EF}_{\mathrm{Zn}}$ in both sites (Figure 1a and Table 1); and (iii) the known light isotope signature of $\mathrm{Zn}$ in $\mathrm{PM}$ emitted from metallurgical and coal combustion processes. ${ }^{15-17}$ Significant contribution from brake wear to $\mathrm{Cu}$ enrichment in $\mathrm{PM}_{10}$ is supported by (i) the correlation between the $\mathrm{EF}_{\mathrm{Cu}}, \mathrm{EF}_{\mathrm{Fe}}$ and $\mathrm{EF}_{\mathrm{Sb}}$, which are typical tracers of brake wear (Figure 3), and (ii) the $\mathrm{Cu} / \mathrm{Sb}$ ratios in the $\mathrm{PM}_{10}$ (Table 1) which are close to the $\mathrm{Cu} / \mathrm{Sb}$ ratios previously reported for brake wear particles. ${ }^{47,54}$

In London, we propose that $\mathrm{Zn}$ and $\mathrm{Cu}$ in $\mathrm{PM}_{2.5-80}$ are dominated by non-exhaust emissions from road vehicles. The correlation between $\delta^{66} \mathrm{Zn}_{\text {IRMM }}$ and $\mathrm{EF}_{\mathrm{Sb}}$ (Figure 2c), and the similarity between $\delta^{66} \mathrm{Zn}_{\text {IRMM }}$ of the $\mathrm{PM}_{2.5-80}$ samples enriched in $\mathrm{Zn}$ (Table 1) and of ore minerals typically used in the production of tires and galvanized stee ${ }^{12-14}$ support this idea. The $\delta^{65} \mathrm{Cu}_{\mathrm{AE} 633}$ in the $\mathrm{PM}_{2.5-80}$ collected during winter and late autumn is heavier than during the other seasons, and we propose that this is due to the dominant contribution of isotopically heavy $\mathrm{Cu}$ in residual particles from fossil fuel combustion, as previously found for $\mathrm{Zn}$ in PM from smelting and coal combustion. ${ }^{13,16,17} \mathrm{The} \mathrm{Cu} / \mathrm{Sb}$ ratios of $\mathrm{PM}_{2.5-80}(\mathrm{Cu} / \mathrm{Sb}=19 \pm 7)$ are significantly higher than those typically found in brakes $(\mathrm{Cu} / \mathrm{Sb}=4.6 \pm 2.3)^{47,54}$ and those of 
$350 \mathrm{PM}_{10}$ collected in Barcelona $(\mathrm{Cu} / \mathrm{Sb}=9 \pm 2$ ) (Table 1$)$. The $\delta^{65} \mathrm{Cu}_{\mathrm{AE} 633}$ and the $\mathrm{Cu} / \mathrm{Sb}$ ratios of $351 \mathrm{PM}_{2.5-80}$ collected during spring and summer in London are closer to those of $\mathrm{PM}_{10}$ in 352 Barcelona (Table 1 and Figure 4). These conclusions are in line with the strong correlation 353 between the $\delta^{65} \mathrm{Cu}_{\mathrm{AE} 633}$ and the $\mathrm{Cu} / \mathrm{Sb}$ ratios $\left(\mathrm{R}^{2}=0.820\right)$ in the PM (Figure 2f), the 354 significantly isotopic heavier $\mathrm{Cu}$ found in London compared to Barcelona, and the 355 contribution of brake wear particles in Barcelona which are typically smaller than $10 \mu \mathrm{m} .{ }^{48,49}$

\subsection{Zinc and $\mathrm{Cu}$ isotope signatures in atmospheric particulate matter: a global perspective}

Figure 5 shows $\mathrm{Zn}$ and $\mathrm{Cu}$ isotope signatures determined in atmospheric $\mathrm{PM}$ collected from cities in Europe and South America (Barcelona, London, Metz and São Paolo) ${ }^{19,20}$ and over the North Atlantic Ocean. ${ }^{18,21}$ In an attempt to characterise potential isotope signatures of natural and anthropogenic sources, we also plot the measured isotope ratios of various different source materials.

With respect to $\mathrm{Zn}$, we constrain the isotope signature of natural sources (wind-blown mineral dust and soil) using values determined for igneous rocks. ${ }^{11}$ The anthropogenic signatures include (i) ore concentrates and sphalerite ${ }^{12-14}$ representing non-exhaust traffic sources (i.e., tire wear, galvanised steel), and (ii) PM collected around smelters and from coal-fired power plants representing PM from high temperature processes. ${ }^{15,17,20}$ As shown in Figure 5, we find that the isotopic compositions of $\mathrm{Zn}$ in PM collected over the North Atlantic region overlap mostly with those in ore concentrates and minerals. ${ }^{11-14,18,21}$ This suggests that either natural sources from wind-blown mineral dust or anthropogenic sources derived from non-exhaust traffic emissions are dominant. Isotopically light $\mathrm{Zn}$ is dominant in most PM collected in São Paulo and Barcelona, ${ }^{20}$ and we propose that this reflects a possible control of $\mathrm{Zn}$ from high temperature processes. This is supported by previous work that shows that trace element concentrations in PM in Barcelona and São Paulo are affected by metallurgical emissions and biomass burning, respectively. ${ }^{22,32,33}$ The isotope signatures in PM collected in Metz and in time series in London are in good agreement with the isotopic composition of sphalerite, i.e., non-exhaust traffic emissions.

With respect to $\mathrm{Cu}$, the isotope signatures in PM collected in Barcelona and over the North Atlantic region overlap with the signature for primary $\mathrm{Cu}$ sulphides $\left(\delta^{65} \mathrm{Cu}_{\mathrm{AE} 633}=-1\right.$ to $+1 \%$ ). ${ }^{18,21,22}$ The $\mathrm{Cu}$ signatures in $\mathrm{PM}_{2.5-80}$ collected in London are significantly different from the $\delta^{65} \mathrm{Cu}_{\mathrm{AE} 633}$ in natural dust, most probably due to the influence of combustion emissions during the winter season. ${ }^{13,16,17}$

Figure 5 suggests that the cities investigated so far have their own 'isotope signature' and we propose that the isotope fingerprints reflect the importance of emissions from high temperature processes and non-exhaust traffic emissions such as brake and tire wear. These observations are among the first to place constraints on the use of $\mathrm{Zn}$ and $\mathrm{Cu}$ isotopes as tracers of anthropogenic sources in atmospheric PM and support previous hypothesis suggesting that smelting and combustion induce a significant isotope fractionation. 


\section{Acknowledgements}

393 R.O.G. thanks The European Commission (FP7-PEOPLE-2012-IEF) for funding the project 394 ISOTRACE (proposal 329878). The authors wish to thank the MAGIC group and in 395 particular Katharina Kreissig at Imperial College for their assistance in the laboratories, 396 Emma Humphreys-Williams (Natural History Museum) for conducting the ICP-OES 397 analysis, and the important feedback provided by three reviewers. Fraser Wigley is thanked 398 for his help during the collection of samples in London.

\section{Supporting Information}

401 Further details regarding the sampling locations in Barcelona, ion exchange procedure, mass 402 bias correction for $\mathrm{Zn}$ isotope analysis and analytical data are detailed in the Supporting 403 information. This information is available free of charge via the Internet at 404 http://pubs.acs.org/. 
Table 1. Concentrations, EF and isotope signatures in PM collected in Barcelona $\left(\mathrm{PM}_{10}\right)$ and London $\left(\mathrm{PM}_{2.5-80}\right)$. * sample $\mathrm{S} 5$ has not been considered to calculate the average $\mathrm{EF}_{\mathrm{Cd}}$.

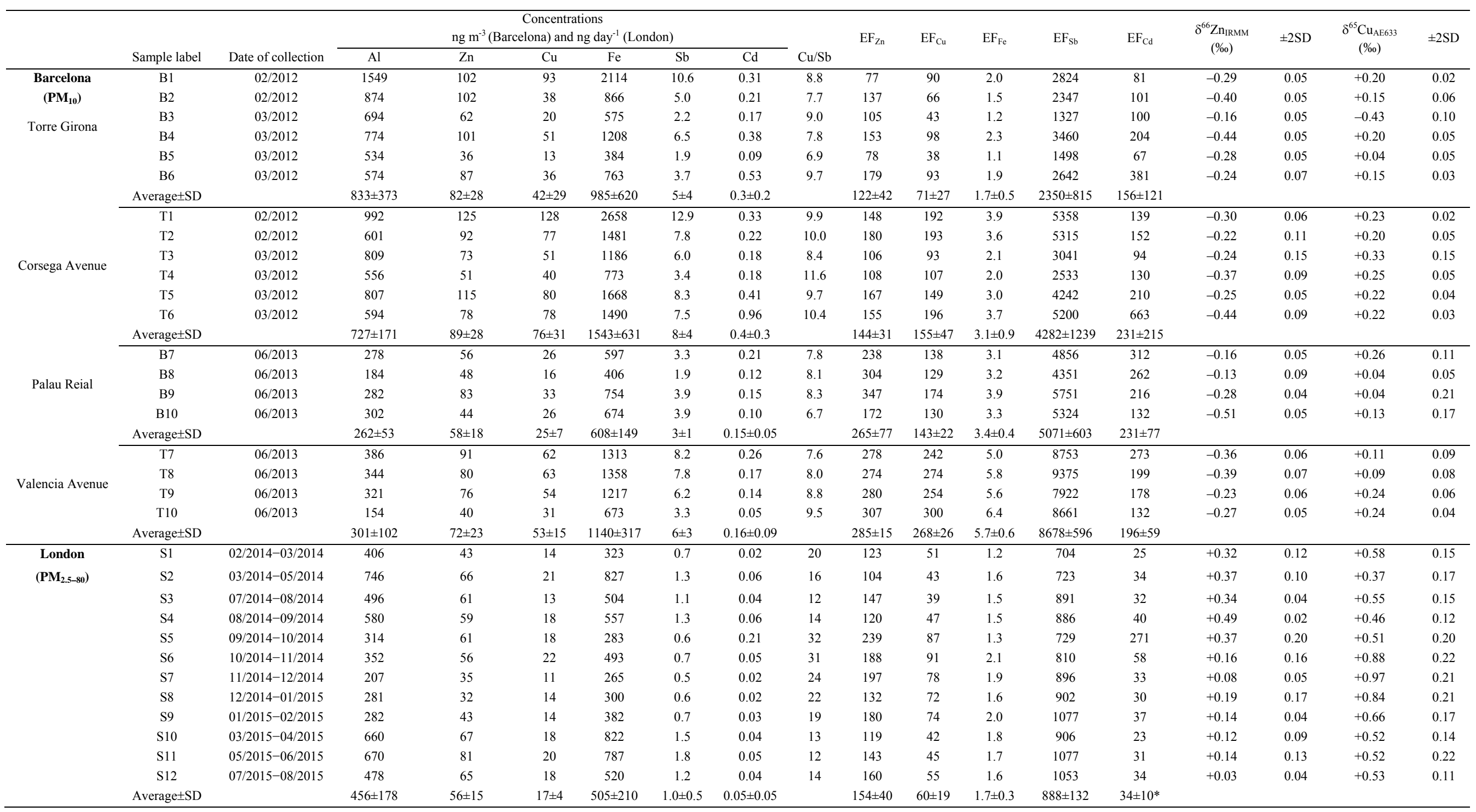



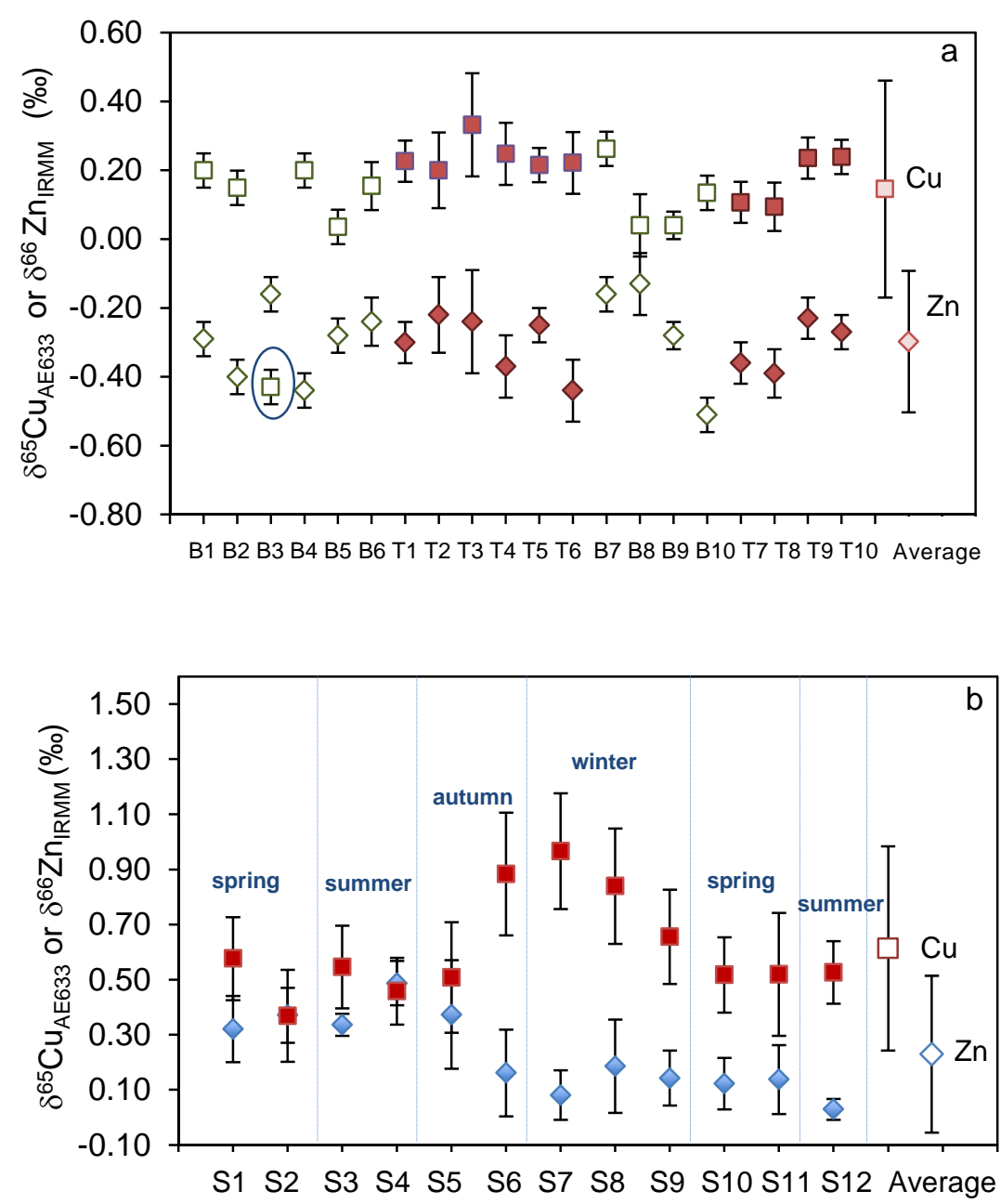

Figure 1. a) Variability in the $\mathrm{Zn}$ (diamonds) and $\mathrm{Cu}$ (squares) isotope signatures (expressed as $\delta^{66} \mathrm{Zn}_{\text {IRMM }}$ and $\delta^{65} \mathrm{Cu}_{\mathrm{AE} 633}$, respectively) in PM collected in Barcelona at Torre Girona (B1-B6) and Corsega (T1-T6) during autumn 2012, and at Palau Reial (B7-B10) and Valencia (T7-T10) during spring 2013. Open and closed symbols represent low traffic and high traffic sites, respectively. The sample B3 is circled as it shows an anomalous value for $\delta^{65} \mathrm{Cu}_{\mathrm{AE} 633}$. b) Zinc and $\mathrm{Cu}$ isotope variability in PM collected between February 2014 and August 2015 in London. Average $\mathrm{Zn}$ and $\mathrm{Cu}$ isotopic compositions are also shown in the figures. Error bars represent the $2 \sigma$ standard deviation of repeated sample measurements $(n \geq 3)$. 

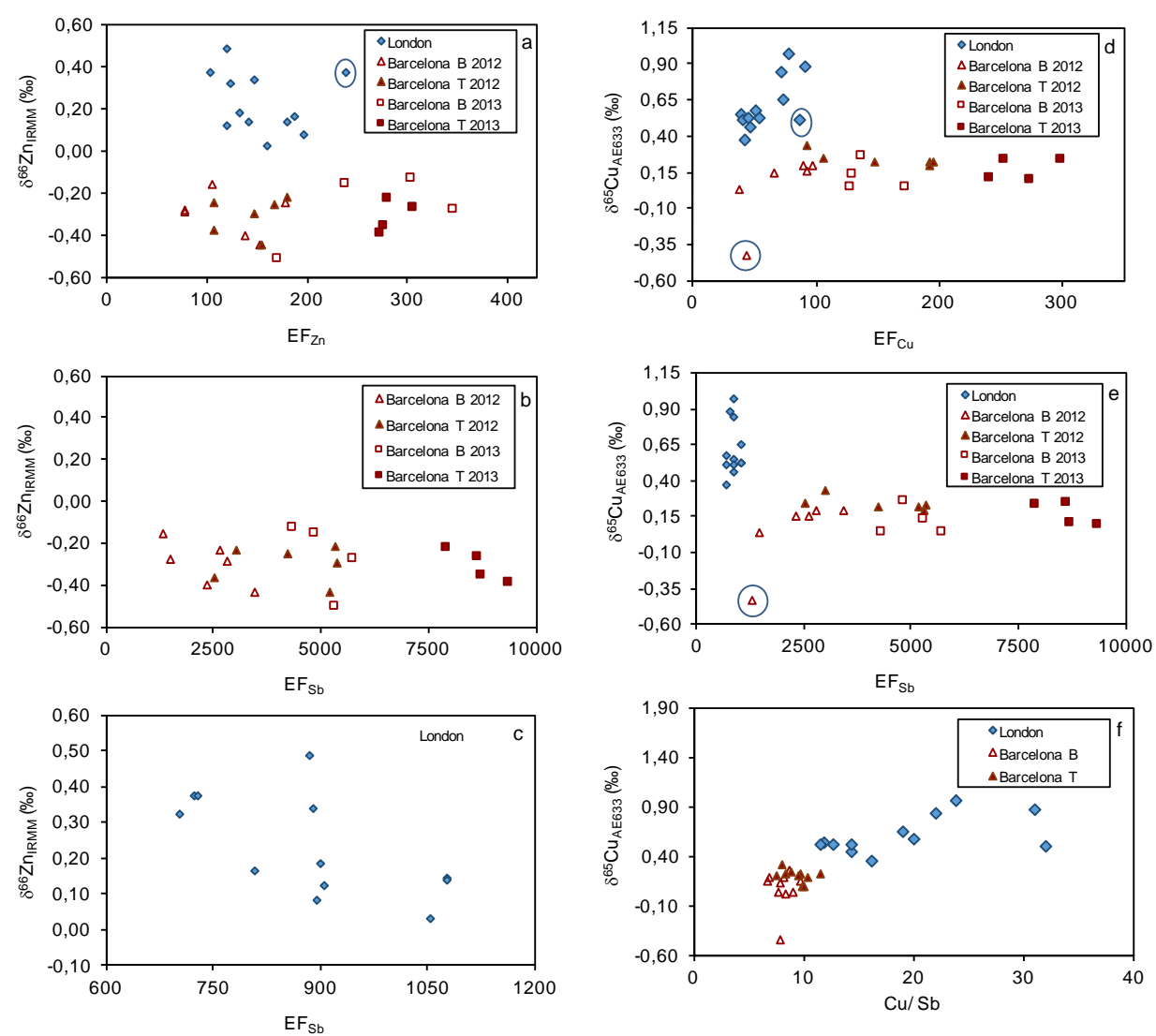

Figure 2. a) Zinc isotope composition vs. the $\mathrm{EF}$ of $\mathrm{Zn}\left(\mathrm{EF}_{\mathrm{Zn}}\right)$. The anomalous value for S5 in London (circled) is discussed in the text. b) and c) Zinc isotope compositions for PM collected in Barcelona and London, respectively, plotted vs. $\mathrm{EF}_{\mathrm{Sb}}$. d) Copper isotope compositions vs. $\mathrm{EF}_{\mathrm{Cu}}$ in PM analysed during this study. Samples S5 and B3 are circled, as they do not follow the general trends. e) Copper isotope compositions plotted against $\mathrm{EF}_{\mathrm{Sb}}$. Sample B3 is circled and discussed in the text. f) Copper isotope compositions vs. $\mathrm{Cu} / \mathrm{Sb}$ ratios. Open and closed symbols represent low traffic (B) and high traffic $(\mathrm{T})$ sites, respectively. 

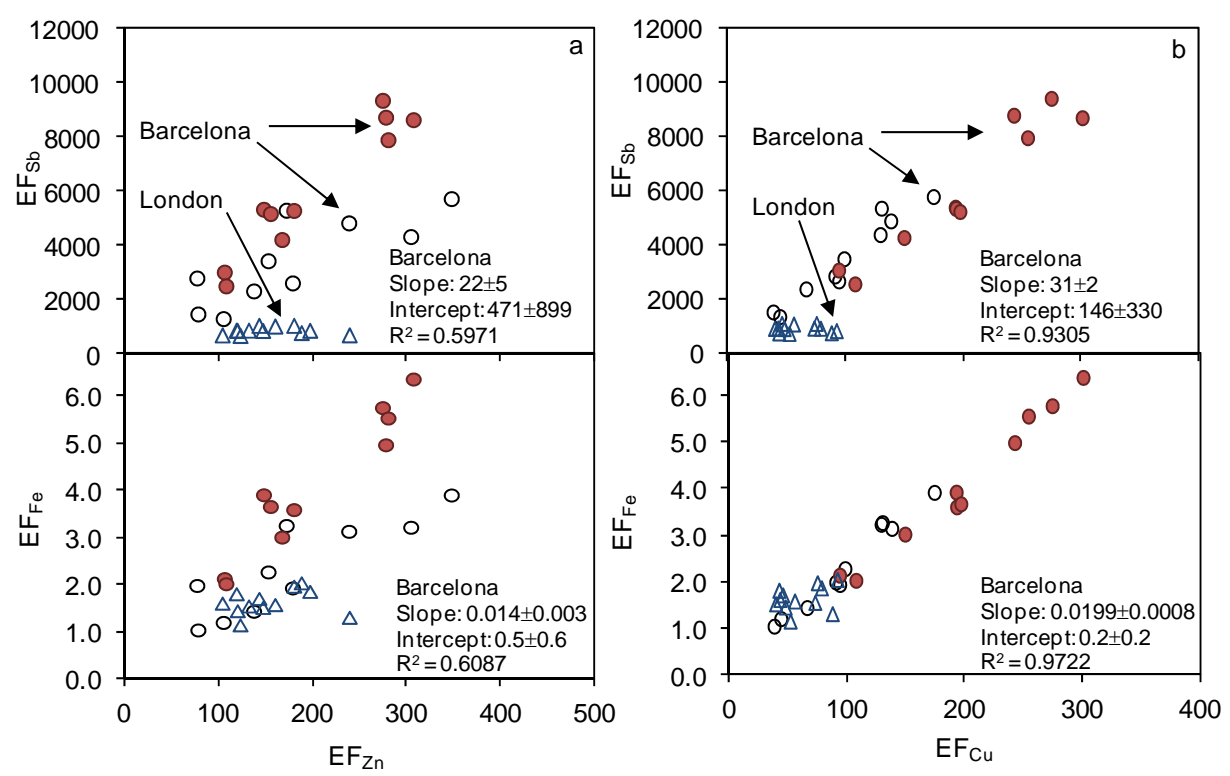

Figure 3. Relationship between the EF of $\mathrm{Zn}, \mathrm{Sb}$ and $\mathrm{Fe}$ (panel a) and the $\mathrm{EF}$ of $\mathrm{Cu}$, $\mathrm{Sb}$ and $\mathrm{Fe}$ (panel b) in PM collected in Barcelona (circles) and London (triangles). Open and closed circles represent low traffic and high traffic sites in Barcelona, respectively. The slopes $( \pm 1 \mathrm{SD})$, intercepts $( \pm 1 \mathrm{SD})$ and $\mathrm{R}^{2}$ of the regression lines for PM collected in Barcelona are given in the panels. 

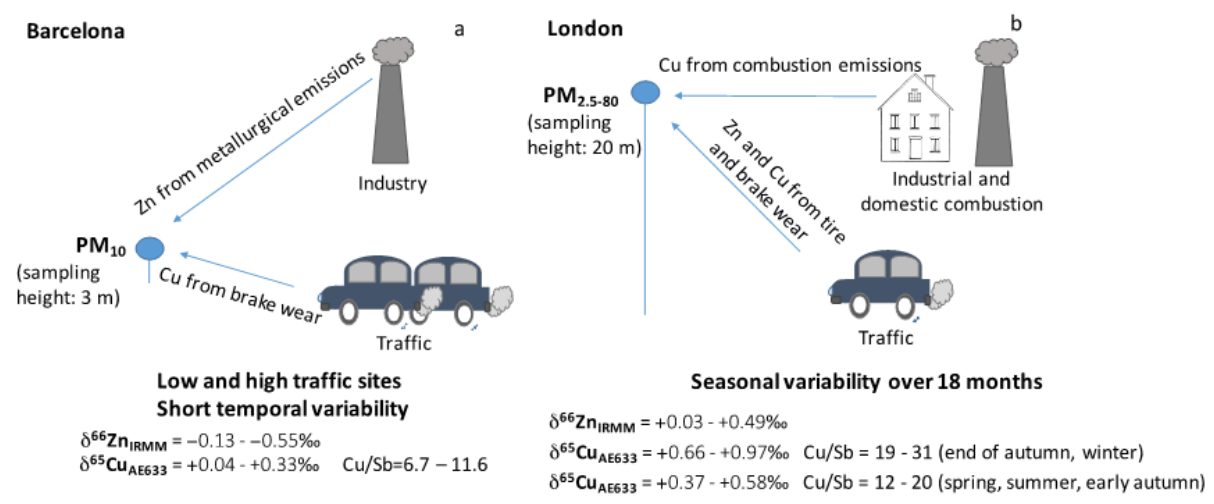

Figure 4. Proposed conceptual model of possible controls of $\mathrm{Zn}$ and $\mathrm{Cu}$ isotope signatures in fine PM in Barcelona (panel a) and coarse PM in London (panel b) derived from this study. In Barcelona, $\mathrm{Zn}$ and $\mathrm{Cu}$ are dominated by emissions from metallurgical industries and from non-exhaust vehicle emissions (brake wear), respectively. In London, $\mathrm{Zn}$ and $\mathrm{Cu}$ are both largely dominated by emissions from non-exhaust vehicle sources, unless during winter, where the heavy $\delta^{65} \mathrm{Cu}_{\mathrm{AE} 633}$ suggests an increased contribution from fossil fuel combustion. 

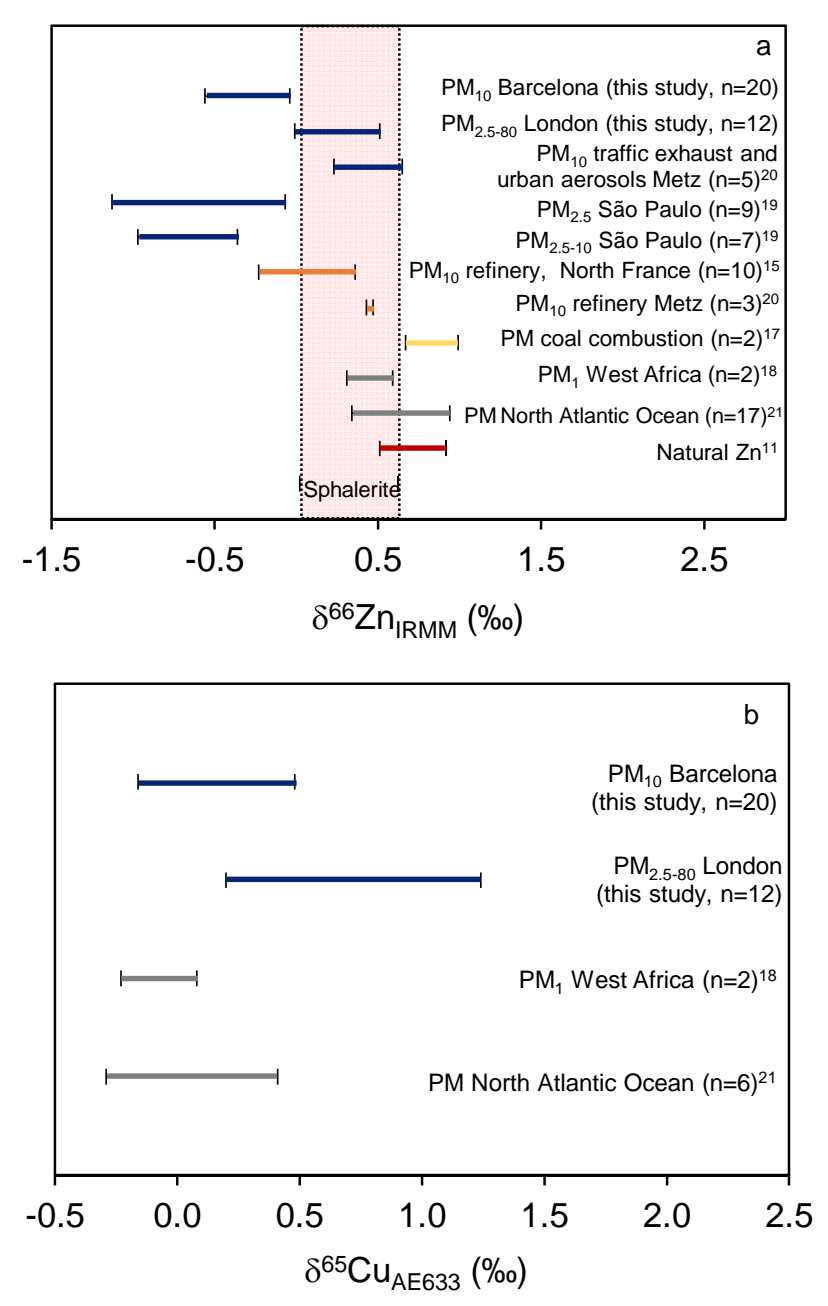

Figure 5. Zinc (panel a) and $\mathrm{Cu}$ (panel b) isotope compositions in PM collected at different locations around the world. The range of $\delta^{66} \mathrm{Zn}_{\text {IRMM }}$ determined for sphalerite and ore concentrates (literature and this study) is shown using the shaded area. ${ }^{12-14}$ The $\delta^{66} \mathrm{Zn}_{\text {IRMM }}$ in rocks ranges between +0.52 and $+0.92 \%$ (panel a), and the $\delta^{65} \mathrm{Cu}_{\mathrm{AE} 633}$ in $\mathrm{Cu}$ sulphides ranges between -1 and $+1 \%{ }^{11,22}$ The $\delta^{66} \mathrm{Zn}_{\text {Lyon }}$ and $\delta^{65} \mathrm{Cu}_{\text {NIST976 }}$ taken from the literature were normalised to $\delta^{66} \mathrm{Zn}_{\text {IRMM }}$ and $\delta^{65} \mathrm{Cu}_{\mathrm{AE} 633}$, respectively, assuming an isotope offset of $\Delta^{66} \mathrm{Zn}_{\text {IRMM-Lyon }}=+0.32 \%$ and no isotope offset for $\mathrm{Cu}\left(\Delta^{65} \mathrm{Cu}_{\text {NIST976-AE633 }} \approx-0.01 \pm 0.04 \%\right.$ ) ${ }^{11,42}$ Data obtained during this study and other cities in Europe and South America are presented in blue color whereas data from literature for PM from smelters and coal-fired power plants is shown in orange and yellow, respectively. Additional data for natural PM and natural sources of $\mathrm{Zn}$ are presented in grey and red, respectively. 


\section{References}

1. Tositti, L.; Brattich, E.; Masiol, M.; Baldacci, D.; Ceccato, D.; Parmeggiani, S.; Stracquadanio, M.; Zappoli, S., Source apportionment of particulate matter in a large city of southeastern Po Valley (Bologna, Italy). Environ Sci Pollut Res 2014, 21, (2), 872-890.

2. Dutton, S. J.; Vedal, S.; Piedrahita, R.; Milford, J. B.; Miller, S. L.; Hannigan, M. P., Source Apportionment Using Positive Matrix Factorization on Daily Measurements of Inorganic and Organic Speciated PM(2.5). Atmospheric environment (Oxford, England : 1994) 2010, 44, (23), 2731-2741.

3. Wiederhold, J. G., Metal Stable Isotope Signatures as Tracers in Environmental Geochemistry. Environmental Science \& Technology 2015, 49, (5), 2606-2624.

4. Song, X.-H.; Polissar, A. V.; Hopke, P. K., Sources of fine particle composition in the northeastern US. Atmospheric Environment 2001, 35, (31), 5277-5286.

5. Al-Masri, M. S.; Al-Kharfan, K.; Al-Shamali, K., Speciation of Pb, Cu and Zn determined by sequential extraction for identification of air pollution sources in Syria. Atmospheric Environment 2006, 40, (4), 753-761.

6. Councell, T. B.; Duckenfield, K. U.; Landa, E. R.; Callender, E., Tire-Wear Particles as a Source of Zinc to the Environment. Environmental Science \& Technology 2004, 38, (15), 4206-4214.

7. Batonneau, Y.; Bremard, C.; Gengembre, L.; Laureyns, J.; Le Maguer, A.; Le Maguer, D.; Perdrix, E.; Sobanska, S., Speciation of PM10 Sources of Airborne Nonferrous Metals within the 3-km Zone of Lead/Zinc Smelters. Environmental Science \& Technology 2004, 38, (20), 5281-5289.

8. Wang, X.; Sato, T.; Xing, B.; Tamamura, S.; Tao, S., Source identification, size distribution and indicator screening of airborne trace metals in Kanazawa, Japan. Journal of Aerosol Science 2005, 36, (2), 197-210.

9. Al-Momani, I. F.; Daradkeh, A. S.; Haj-Hussein, A. T.; Yousef, Y. A.; Jaradat, Q. M.; Momani, K. A., Trace elements in daily collected aerosols in Al-Hashimya, central Jordan. Atmospheric Research 2005, 73, (1-2), 87-100.

10. Fernández, A. J.; Ternero, M.; Barragán, F. J.; Jiménez, J. C., An approach to characterization of sources of urban airborne particles through heavy metal speciation. Chemosphere - Global Change Science 2000, 2, (2), 123-136.

11. Cloquet, C.; Carignan, J.; Lehmann, M.; Vanhaecke, F., Variation in the isotopic composition of zinc in the natural environment and the use of zinc isotopes in biogeosciences: a review. Analytical and bioanalytical chemistry 2008, 390, (2), 451463.

12. John, S. G.; Genevieve Park, J.; Zhang, Z.; Boyle, E. A., The isotopic composition of some common forms of anthropogenic zinc. Chemical Geology 2007, 245, (1-2), 61-69.

13. Sivry, Y.; Riotte, J.; Sonke, J. E.; Audry, S.; Schäfer, J.; Viers, J.; Blanc, G.; Freydier, R.; Dupré, B., Zn isotopes as tracers of anthropogenic pollution from Zn-ore smelters The Riou Mort-Lot River system. Chemical Geology 2008, 255, (3-4), 295 304.

14. Sonke, J. E.; Sivry, Y.; Viers, J.; Freydier, R.; Dejonghe, L.; André, L.; Aggarwal, J. K.; Fontan, F.; Dupré, B., Historical variations in the isotopic composition of atmospheric zinc deposition from a zinc smelter. Chemical Geology 2008, 252, (3-4), 145-157.

15. Mattielli, N.; Petit, J. C. J.; Deboudt, K.; Flament, P.; Perdrix, E.; Taillez, A.; Rimetz-Planchon, J.; Weis, D., Zn isotope study of atmospheric emissions and dry 
depositions within a $5 \mathrm{~km}$ radius of a $\mathrm{Pb}-\mathrm{Zn}$ refinery. Atmospheric Environment 2009, 43, (6), 1265-1272.

16. Ochoa González, R.; Weiss, D. J., Zinc isotope variability in three coal-fired power plants: A predictive model for determining isotopic fractionation during combustion. Environmental Science \& Technology 2015.

17. Borrok, D. M.; Gieré, R.; Ren, M.; Landa, E. R., Zinc Isotopic Composition of Particulate Matter Generated during the Combustion of Coal and Coal + Tire-Derived Fuels. Environmental Science \& Technology 2010, 44, (23), 9219-9224.

18. Dong, S.; Weiss, D. J.; Strekopytov, S.; Kreissig, K.; Sun, Y.; Baker, A. R.; Formenti, P., Stable isotope ratio measurements of $\mathrm{Cu}$ and $\mathrm{Zn}$ in mineral dust (bulk and size fractions) from the Taklimakan Desert and the Sahel and in aerosols from the eastern tropical North Atlantic Ocean. Talanta 2013, 114, 103-109.

19. Gioia, S.; Weiss, D.; Coles, B.; Arnold, T.; Babinski, M., Accurate and Precise Zinc Isotope Ratio Measurements in Urban Aerosols. Analytical Chemistry 2008, 80, (24), 9776-9780.

20. Cloquet, C.; Carignan, J.; Libourel, G., Isotopic Composition of $\mathrm{Zn}$ and $\mathrm{Pb}$ Atmospheric Depositions in an Urban/Periurban Area of Northeastern France. Environmental Science \& Technology 2006, 40, (21), 6594-6600.

21. Little, S. H.; Vance, D.; Walker-Brown, C.; Landing, W. M., The oceanic mass balance of copper and zinc isotopes, investigated by analysis of their inputs, and outputs to ferromanganese oxide sediments. Geochimica et Cosmochimica Acta 2014, $125,673-693$.

22. Kimball, B. E.; Mathur, R.; Dohnalkova, A. C.; Wall, A. J.; Runkel, R. L.; Brantley, S. L., Copper isotope fractionation in acid mine drainage. Geochimica et cosmochimica acta 2009, 73, (5), 1247-1263.

23. Vance, D.; Archer, C.; Bermin, J.; Perkins, J.; Statham, P. J.; Lohan, M. C.; Ellwood, M. J.; Mills, R. A., The copper isotope geochemistry of rivers and the oceans. Earth and Planetary Science Letters 2008, 274, (1-2), 204-213.

24. Balistrieri, L. S.; Borrok, D. M.; Wanty, R. B.; Ridley, W. I., Fractionation of $\mathrm{Cu}$ and $\mathrm{Zn}$ isotopes during adsorption onto amorphous $\mathrm{Fe}(\mathrm{III})$ oxyhydroxide: Experimental mixing of acid rock drainage and ambient river water. Geochimica et cosmochimica acta 2008, 72, (2), 311-328.

25. Borrok, D. M.; Nimick, D. A.; Wanty, R. B.; Ridley, W. I., Isotopic variations of dissolved copper and zinc in stream waters affected by historical mining. Geochimica et cosmochimica acta 2008, 72, (2), 329-344.

26. Bigalke, M.; Weyer, S.; Kobza, J.; Wilcke, W., Stable $\mathrm{Cu}$ and $\mathrm{Zn}$ isotope ratios as tracers of sources and transport of $\mathrm{Cu}$ and $\mathrm{Zn}$ in contaminated soil. Geochimica et Cosmochimica Acta 2010, 74, (23), 6801-6813.

27. Maréchal, C. N.; Télouk, P.; Albarède, F., Precise analysis of copper and zinc isotopic compositions by plasma-source mass spectrometry. Chemical Geology 1999, 156, (1-4), 251-273.

28. Zhu, X. K.; O'Nions, R. K.; Guo, Y.; Belshaw, N. S.; Rickard, D., Determination of natural $\mathrm{Cu}$-isotope variation by plasma-source mass spectrometry: implications for use as geochemical tracers. Chemical Geology 2000, 163, (1-4), 139149.

29. Archer, C., Vance, D.,, Large fractionations in $\mathrm{Fe}, \mathrm{Cu}$, and Znisotopes associated with Archean microbially-mediated sulphides. In Goldschmidt Geochim. Cosmochim. Acta Davos, 2002; Vol. 66 (15A).

30. Mathur, R.; Titley, S.; Barra, F.; Brantley, S.; Wilson, M.; Phillips, A.; Munizaga, F.; Maksaev, V.; Vervoort, J.; Hart, G., Exploration potential of Cu isotope 
fractionation in porphyry copper deposits. Journal of Geochemical Exploration 2009, 102, (1), 1-6.

31. Schleicher, N. J.; Norra, S.; Chai, F.; Chen, Y.; Wang, S.; Cen, K.; Yu, Y.; Stüben, D., Temporal variability of trace metal mobility of urban particulate matter from Beijing - A contribution to health impact assessments of aerosols. Atmospheric Environment 2011, 45, (39), 7248-7265.

32. Minguillón, M. C.; Cirach, M.; Hoek, G.; Brunekreef, B.; Tsai, M.; de Hoogh, K.; Jedynska, A.; Kooter, I. M.; Nieuwenhuijsen, M.; Querol, X., Spatial variability of trace elements and sources for improved exposure assessment in Barcelona. Atmospheric Environment 2014, 89, 268-281.

33. Amato, F.; Viana, M.; Richard, A.; Furger, M.; Prévôt, A. S. H.; Nava, S.; Lucarelli, F.; Bukowiecki, N.; Alastuey, A.; Reche, C.; Moreno, T.; Pandolfi, M.; Pey, J.; Querol, X., Size and time-resolved roadside enrichment of atmospheric particulate pollutants. Atmos. Chem. Phys. 2011, 11, (6), 2917-2931.

34. Harrison, R. M.; Jones, A. M.; Gietl, J.; Yin, J.; Green, D. C., Estimation of the Contributions of Brake Dust, Tire Wear, and Resuspension to Nonexhaust Traffic Particles Derived from Atmospheric Measurements. Environmental Science \& Technology 2012, 46, (12), 6523-6529.

35. Guéguen, F.; Stille, P.; Dietze, V.; Gieré, R., Chemical and isotopic properties and origin of coarse airborne particles collected by passive samplers in industrial, urban, and rural environments. Atmospheric Environment 2012, 62, 631-645.

36. Taylor, S. R., Abundance of chemical elements in the continental crust: a new table. Geochimica et cosmochimica acta 1964, 28, (8), 1273-1285.

37. Wu, Y.-S.; Fang, G.-C.; Lee, W.-J.; Lee, J.-F.; Chang, C.-C.; Lee, C.-Z., A review of atmospheric fine particulate matter and its associated trace metal pollutants in Asian countries during the period 1995-2005. Journal of Hazardous Materials 2007, 143, (1-2), 511-515.

38. Pribil, M. J.; Wanty, R. B.; Ridley, W. I.; Borrok, D. M., Influence of sulfurbearing polyatomic species on high precision measurements of $\mathrm{Cu}$ isotopic composition. Chemical Geology 2010, 272, (1-4), 49-54.

39. Mason, T. F. D.; Weiss, D. J.; Horstwood, M.; Parrish, R. R.; Russell, S. S.; Mullane, E.; Coles, B. J., High-precision $\mathrm{Cu}$ and $\mathrm{Zn}$ isotope analysis by plasma source mass spectrometry Part 1. Spectral interferences and their correction. Journal of Analytical Atomic Spectrometry 2004, 19, (2), 209-217.

40. Peel, K.; Weiss, D.; Chapman, J.; Arnold, T.; Coles, B., A simple combined sample-standard bracketing and inter-element correction procedure for accurate mass bias correction and precise $\mathrm{Zn}$ and $\mathrm{Cu}$ isotope ratio measurements. Journal of Analytical Atomic Spectrometry 2008, 23, (1), 103-110.

41. Arnold, T.; Schönbächler, M.; Rehkämper, M.; Dong, S.; Zhao, F. J.; Kirk, G. J. D.; Coles, B. J.; Weiss, D. J., Measurement of zinc stable isotope ratios in biogeochemical matrices by double-spike MC-ICPMS and determination of the isotope ratio pool available for plants from soil. Analytical and Bioanalytical Chemistry 2010, 398, (7-8), 3115-3125.

42. Moeller, K.; Schoenberg, R.; Pedersen, R. B.; Weiss, D.; Dong, S., Calibration of the New Certified Reference Materials ERM-AE633 and ERM-AE647 for Copper and IRMM-3702 for Zinc Isotope Amount Ratio Determinations. Geostandards and Geoanalytical Research 2012, 36, (2), 177-199.

43. Querol, X.; Alastuey, A.; Rodriguez, S.; Plana, F.; Ruiz, C. R.; Cots, N.; Massagué, G.; Puig, O., PM10 and PM2.5 source apportionment in the Barcelona 
Metropolitan area, Catalonia, Spain. Atmospheric Environment 2001, 35, (36), 64076419.

44. Grigoratos, T.; Martini, G., Brake wear particle emissions: a review. Environ Sci Pollut Res 2015, 22, (4), 2491-2504.

45. Straffelini, G.; Ciudin, R.; Ciotti, A.; Gialanella, S., Present knowledge and perspectives on the role of copper in brake materials and related environmental issues: A critical assessment. Environmental Pollution 2015, 207, 211-219.

46. Loosmore, G. A.; Cederwall, R. T., Precipitation scavenging of atmospheric aerosols for emergency response applications: testing an updated model with new realtime data. Atmospheric Environment 2004, 38, (7), 993-1003.

47. Thorpe, A.; Harrison, R. M., Sources and properties of non-exhaust particulate matter from road traffic: A review. Science of The Total Environment 2008, 400, (13), 270-282.

48. Iijima, A.; Sato, K.; Yano, K.; Tago, H.; Kato, M.; Kimura, H.; Furuta, N., Particle size and composition distribution analysis of automotive brake abrasion dusts for the evaluation of antimony sources of airborne particulate matter. Atmospheric Environment 2007, 41, (23), 4908-4919.

49. Garg, B. D.; Cadle, S. H.; Mulawa, P. A.; Groblicki, P. J.; Laroo, C.; Parr, G. A., Brake Wear Particulate Matter Emissions. Environmental Science \& Technology 2000, 34, (21), 4463-4469. 


\section{TOC}

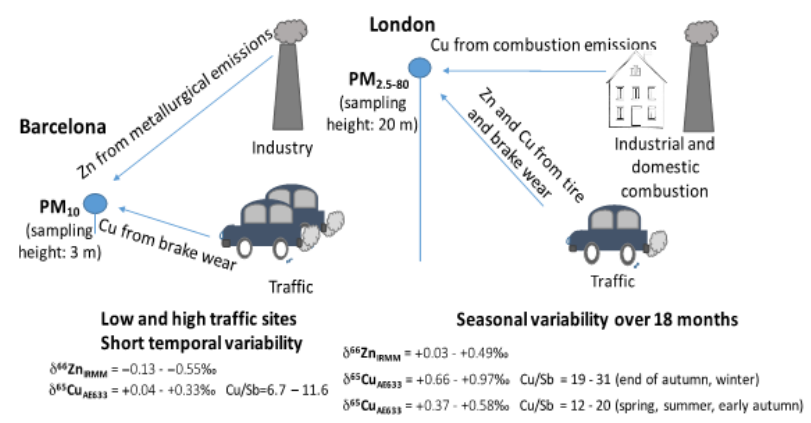

